\section{An Online Plant Diagnostics Module for Extension Master Gardeners}

\author{
Mary Hockenberry Meyer ${ }^{1,4}$, Cynthia Haynes ${ }^{2}$, Denise Ellsworth ${ }^{3}$, \\ Sarah Ellis Williams ${ }^{3}$, Celeste Welty ${ }^{3}$, and Karen Jeannette ${ }^{1}$
}

AdDitional INDEX WORDs. integrated pest management, IPM, pesticide use, training, volunteers, EMG

Summary. The North Central Consumer Horticulture Integrated Pest Management Working Group developed an online learning module entitled, "Introduction to Diagnostics for Master Gardener Volunteers: Approaches to Plant Pest Diagnosis.” The module is online in the campus or learn section of eXtension and is composed of three parts: part 1 covers the difficulties in diagnosing plant problems; part 2 discusses how to gather the information necessary for the diagnostic process; and part 3 covers the Ohio State Fact Sheet, "20 Questions on Plant Diagnostics." The self-paced module takes a minimum of 2 hours to complete, although participants have access to the information for 10 weeks. The module costs $\$ 10$ and the income is distributed between the module author(s), the state which the Extension Master Gardener (EMG) is from, and eXtension. Within 11 months, 451 people purchased the training. Participants reported a higher comfort and knowledge level of diagnostics after taking the training.

$\mathrm{E}$ MGs are Cooperative Extensiontrained volunteers who teach public horticulture and are active in most states in the United States (Meyer, 2007). Providing up-to-date, high quality training, especially in pest management, is critical for volunteer success and maintaining a premier educational program. Questions concerning trees and perennials were found to be the most common for EMGs (Meyer and Jarvis, 2003) and often involve diagnosing and managing pest problems. EMGs are encouraged to use integrated pest management (IPM) in their own gardening practices and in their educational outreach work. IPM is "a long-standing, science-based, decision-making process that identifies and reduces risks from pests and pest management related strategies. It coordinates the use of pest biology, environmental information, and available technology to prevent unacceptable levels of pest damage by the most economical means, while posing the least possible risk to people, property, resources, and the environment" (North Central Integrated Pest Management

This paper was part of the workshop "The Growing Involvement of Horticulture in eXtension: Updates and Opportunities" held 27 Sept. 2011 at the ASHS Conference, Waikoloa, HI, and sponsored by the eXtension (EEXT) Working Group.

${ }^{1}$ University of Minnesota, St. Paul, MN 55108

${ }^{2}$ Iowa State University, Ames, IA 50011

${ }^{3}$ The Ohio State University, Columbus, OH 43210

${ }^{4}$ Corresponding author. E-mail: meyer023@umn.edu.
Center, 2010). EMGs have an opportunity to teach best environmental practices each time they are asked to diagnose a plant problem, so their understanding and knowledge of diagnostics is critical.

Although the term IPM is not well understood by gardeners, they are often practicing IPM tactics because environmental impacts are important to them and affect their pest control decisions (Matheny, 2009). An online survey of 3842 EMGs in 11 north-central U.S. states indicated they personally engaged in a range of IPM practices, including prevention, monitoring, cultural, and chemical controls. (Meyer et al., 2010). However, $81 \%$ indicated a need for more training in identifying diseases, and $65 \%$ say they needed more training in identifying insects. Only 16\% indicated they had received advanced pest management training within the past five years (Meyer et al., 2010). In response to this acute need for advanced training, the North Central Consumer Horticulture IPM Working Group developed an online learning module entitled, "Introduction to Diagnostics for Master Gardener Volunteers: Approaches to Plant Pest Diagnosis." The goal of the module was to increase EMG confidence and knowledge in the diagnostic process, which usually involves answering the most common question from the public: "what's wrong with my plant?"

\section{Methods and materials}

The online module was developed in 2010 using the Moodle course management system (Perth, Australia), Camtasia-based presentations (TechSmith, Okemos, MI), and narrated Powerpoint presentations (Microsoft, Redmond, WA). The module was publically offered online on the campus or learn page of eXtension in Jan. 2011 (eXtension, 2012; Williams and Ellsworth, 2011). Participants pay $\$ 10$ through a PayPal (eBay, San Jose, CA) registration and are then given an access code to begin their self-paced learning. Although participant's completion time varies, most are expected to take 2 to $4 \mathrm{~h}$ to complete the module; however, all participants have access to the training for 10 weeks. At the end of the module, participants complete a brief seven-question survey on their learning and knowledge change along with demographic information in exchange for a certificate of completion. The three-credit certificate of completion can then be used to verify their training and given to their state EMG coordinator to count as advanced training, which is required for most EMG volunteers to continue in the program.

The $\$ 10$ module cost is distributed three ways: $20 \%$ goes to the module author(s), $55 \%$ goes to the state which the EMG is from, and $25 \%$ supports eXtension administration and maintenance of the module online. This distribution gives an incentive for the author to develop other training modules, support for eXtension in administration of the website and registration, and income for the state EMG programs. Promotion of the training by individual states achieves their goal of providing advanced training to EMGs and results in program income to assist with the state's EMG program. Although the income distribution may seem complex, the funds reside in eXtension and are withdrawn only upon presentation of appropriate invoices to eXtension administration.

The self-paced module is composed of three parts. Part $l$ is an overview of the broad range of plant problems and complexities involving the plant identification, site, environment, and recent history. Part 2 discusses how to gather the information 
necessary for the diagnostic process including a list of questions and a suggested sequence for asking the questions. Part 3 covers the Ohio State Fact Sheet, "20 Questions on Plant Diagnostics" (Boggs et al., 2008), which can be printed as a resource guide for dealing with individual plant problems. Participants listen to an audio program that plays along with images and words in an automated slide show. Illustrations showing numerous real-life plant problems guide participants through the three parts. The purpose of the module is to give EMGs a guide to the process of diagnostics, not specific content on actual pests.

The diagnostic module was announced and promoted to EMG coordinators in the 11 north-central U.S. states via e-mail in 2011. A posting on the EMG blog in early 2011 (Jeannette, 2011) has attracted 100200 unique page views per month, with an average of 4 min viewing time per page. The module was also promoted by distributing a postcard with the URL at the International Master Gardener Conference in West Virginia, 9-12 Oct. 2011 and in a formal presentation at the ASHS Annual Conference in Sept. 2011 (Meyer et al., 2011).

\section{Results and discussion}

Within 11 months, 451 participants from 22 states had paid to take the online diagnostics module. Not all participants completed the survey at the end of the module; however, only those completing the survey received a certificate of completion. Responses to the seven-question survey at the end of the module indicated that $12 \%$ had been EMGs for less than one year; a majority, $47 \%$, had been EMGs from one to five years; $26 \%$ had been in the program from six to 10 years; and $15 \%$ were EMGs for more than 10 years. Although the module was developed and promoted in the northcentral U.S. region, participants were from 22 states as follows: Ohio (80), Illinois (40), Minnesota (32), Michigan (29), Virginia (11), Pennsylvania (10), Iowa (9), Nebraska (9), Washington (9), Vermont (7), Indiana (5), North Carolina (3), Texas (3), Wisconsin (3), Kentucky (2), New York (2), Oregon (2), California (1), Florida (1), Georgia (1), Kansas (1), and Tennessee (1). Not all participants are completing the final survey, and thus total paid participants do not equal the cumulative states total or the survey responses.

When asked how diagnostic questions come to participants, $88 \%$ indicated "in person," 65\% "over the phone," $39 \%$ via e-mail, $8 \%$ through a website, and $6 \%$ indicated "other." Before completing the program, participants indicated their comfort and knowledge level with plant pest diagnostics was limited; however, after the program, both comfort and knowledge increased (Tables 1 and 2). About one-third of the participants were somewhat comfortable or knowledgeable before training, while nearly two-thirds indicated somewhat comfortable or knowledgeable after the training (Tables 1 and 2 ).

Although $41 \%$ of the online learners indicated they had been in the EMG program for six years or more, few indicated a high level of comfort or knowledge of plant pest diagnostics before and after the training. These results show the complexity of this subject and the need for continual diagnostic training. Almost all states require EMG volunteers to annually attend advanced training classes; however, few states require that the annual training must be in diagnostics. These results indicate that few EMGs who took this class are highly comfortable or knowledgeable with diagnostics. It is also likely that EMGs who are knowledgeable in diagnostics would see little need to enroll in an introductory class in diagnostics as they already are knowledgeable in this subject.

IPM is a complex topic that must be understood by EMGs before it can be taught to others. A 2007 University of Maryland Master Gardener report indicated that only $28 \%$ of reporting home gardeners learned from EMGs how to reduce the use of pesticides "very much" or "a good deal" (Traunfeld and Hessey, 2007). This finding reflects a need for improved educational materials for EMGs to use in their IPM outreach work along with an emphasis on teaching IPM. Professional lawn care and landscape maintenance firms indicated they were not practicing IPM; however, they did indicate they used scouting, alternative management strategies, and pest control measures consistent with IPM (Braman et al., 1998).

EMGs with advanced pest management training were more confident in making IPM recommendations to other gardeners and were much more likely to use IPM practices than EMGs without advanced training (Meyer et al., 2010). The use of complex tactics, such as biological controls,

Table 1. Participants indication of their comfort level in diagnosing plant problems before $(n=265)$ and after $(n=249)$ completing an online diagnostic training module.

\begin{tabular}{lcc}
\hline & \multicolumn{2}{c}{ Participant responses (\%) } \\
\cline { 2 - 3 } Survey question & $\begin{array}{c}\text { Before } \\
\text { training }\end{array}$ & $\begin{array}{c}\text { After } \\
\text { training }\end{array}$ \\
\hline I am very comfortable with diagnostics. & 1 & 12 \\
I am somewhat comfortable with diagnostics. & 36 & 76 \\
I am not comfortable with diagnostics. & 43 & 11 \\
I am very uncomfortable with diagnostics. & 10 & 1 \\
I am brand new to diagnostics. & 12 & $\mathrm{NA}$ \\
\hline
\end{tabular}

Table 2. Participants indication of their knowledge level of diagnosing plant problems before $(n=248)$ and after $(n=251)$ completing an online diagnostic training module.

\begin{tabular}{lcc}
\hline & \multicolumn{2}{c}{ Participant responses (\%) } \\
\cline { 2 - 3 } Survey question & $\begin{array}{c}\text { Before } \\
\text { training }\end{array}$ & $\begin{array}{c}\text { After } \\
\text { training }\end{array}$ \\
\hline I am very knowledgeable about diagnostics. & 1 & 9 \\
I am somewhat knowledgeable about diagnostics. & 37 & 72 \\
I am slightly knowledgeable about diagnostics. & 43 & 18 \\
I know very little about diagnostics. & 11 & 1 \\
I am brand new to diagnostics. & 7 & $\mathrm{NA}$ \\
\hline
\end{tabular}


may require special training (Sadof et al., 2004). Participatory research along with a reduction in pesticide use was necessary for EMGs to adopt long-term use of biological pest controls as part of an IPM program; using just one of these tactics alone was not sufficient for participant's adoption of biological controls (Sadof et al., 2004). Ohio EMGs were found to practice $80 \%$ or more of the IPM techniques listed in a 2006 survey (Kohli, 2006). Additionally, these EMGs had high IPM knowledge levels and were most interested in obtaining more information regarding disease-resistant plants and identifying insects and their damage (Kohli, 2006).

Gardeners indicated willingness to pay for scouting $(52 \%)$, one of the primary tactics of IPM, and that they also favored reducing pesticide use (52\%); however, only $13 \%$ were willing to reduce pesticides if it meant a loss in plant quality (Braman et al., 1998). Georgia homeowners showed $64 \%$ used insecticides on their landscapes [likely for fire ants (Solenopsis)], and $68 \%$ applied herbicides for lawn weeds (Varlamoff et al., 2001). In a more recent study, $94 \%$ of homeowners surveyed indicated a willingness to accept some number of insect pests or damage to plants while $49 \%$ regularly monitored their landscape for pests, and $50 \%$ indicated they would use knowledge about the life cycle of a pest to help with control (Matheny, 2009). A larger survey in Pennsylvania found that $71 \%$ of gardeners identified insect pests before deciding to treat them and $74 \%$ regularly monitored their landscape for problems, both IPM tactics (Sellmer et al., 2003). Gardeners indicated they were most interested in learning more about specific IPM approaches including recognizing beneficial insects (71\%), using natural enemies to control pests $(69 \%)$, and choosing leasttoxic pesticides for humans $(63 \%)$ and the environment (66\%); however, less than $50 \%$ of respondents indicated a desire to learn more about any of the pesticide-related items (Matheny, 2009).

An easily accessible online class can be an economical and efficient method for training EMGs. Complex topics such as diagnostics and IPM need to be offered/taught for EMGs to gain the confidence and knowledge necessary for dealing with public gardening questions. Gardeners are interested in ecologically sound means of pest control and using IPM, even if they do not readily understand the IPM acronym. Additional online training, for all gardeners in specific IPM tactics, such as biological controls and pest life cycles are timely and should be offered to these audiences.

\section{Literature cited}

Boggs, J., E. Draper, J. Chatfield, S. Ellis, and M. Boehm. 2008. 20 questions on plant diagnostics. 14 Jan. 2012. <http:// ohioline.osu.edu/hyg-fact/3000/pdf/ PP401_03.pdf>.

Braman, S., J. Latimer, and C. Robacker. 1998. Factors influencing pesticide use and integrated pest management implementation in urban landscapes: A case study in Atlanta. HortTechnology 18:145-149.

eXtension. 2012. eXtension. 21 Feb. 2012. <http://www.extension.org/>.

Jeannette, K. 2011. Introduction to (plant) diagnostics for Master Gardenersonline module. 12 Jan. 2012. <http:// blogs.extension.org/mastergardener/ $2011 / 02 / 04 /$ introduction-to-plantdiagnostics-for-master-gardeners-onlinemodule $/>$.

Kohli, M.M. 2006. The level of integrated pest management adoption among Ohio Master Gardeners. The Ohio State Univ., Columbus, M.S. Thesis.

Matheny, A.M. 2009. Home gardener preferences, perceptions, knowledge and behaviors associated with pest management strategies and information acquisition.
Univ. Maryland, MS Thesis. 4 Jan. 2012. <http://drum.lib.umd.edu/handle/ $1903 / 9320>$.

Meyer, M. 2007. The Master Gardener program 1972-2005. Hort. Rev. 33: 393-420.

Meyer, M., C. Haynes, and D. Ellsworth. 2011. What's wrong with my plant? An online plant diagnostics module for Master Gardeners. HortScience 46:S86. (abstr.).

Meyer, M., R. Burrows, K. Jeannette, C. Welty, and A.R. Boyson. 2010. Master Gardener's confidence and use of integrated pest management. Hort Technology 20:812-816.

Meyer, M. and B. Jarvis. 2003. Electronic "ask a Master Gardener" answers gardening questions. J. Ext. 4l(1). 7 Jan. 2012. <http://www.joe.org/joe/2003february/ iw3.php>.

North Central Integrated Pest Management Center. 2010. What is IPM? 28 Dec. 2011. <http://www.ncipmc.org/ whatisipm.cfm>.

Sadof, C., R. O’Neil, F. Heraux, and R. Weidenmann. 2004. Reducing insecticide use in home gardens: Effects of training and volunteer research on adoption of biological control. HortTechnology 14: 149-154.

Sellmer, J.C., L.M. Kelley, and D.J. Suchanic. 2003. An interactive survey to assess consumer knowledge about landscape plant health care and IPM practices. J. Ext. 4l(2). 7 Jan. 2012. <http:// www.joe.org/joe/2003april/rb4.php>.

Traunfeld, J. and R. Hessey. 2007. Report of the University of Maryland Master Gardener plant clinic survey. Maryland Coop. Ext., Ellicott City.

Varlamoff, S., W.J. Florkowski, J.L. Jordan, J. Latimer, and K. Braman. 2001. Georgia homeowner survey of landscape management practices. HortTechnology 11 : 326-331.

Williams, S.E. and D. Ellsworth. 2011. Introduction to diagnostics for Master Gardener volunteers. 12 Jan. 2012. $<$ http://campus.extension.org/course/ enrol.php? id=396>. 